\title{
The Constitutional Role of Judicial Service Commission in Protecting Independence of the Judiciary
}

\author{
Alexander Martin Saba*
}

\begin{abstract}
The judiciary is constitutionally vested with power to dispense justice to the citizens without fear, favor, ill-will or affection. This sacred function can only be effectively discharge if the judiciary exercises independence without any iota of interference from any person, body or organ. If that is the case it calls for the judiciary to defend its independence whenever interference is done or is likely to be done to it. This role, at any rate, is not intended to be discharged by individual judges. The appropriate organ to discharge this function is the Judicial Service Commission (JSC) which is mandated to ensure self-regulation of the judiciary. Judiciary is therefore expected to be at the frontline to always defend and promote the independence of the judiciary. This article, therefore, seeks to unveil whether or not the JSC of Tanzania is capable of protecting independence of our judiciary to enable the judges to perform their duty without reprisals or intimidations from any quarter. The author is of the view that a lot has to be done in terms of structure and mandates to realize rebirth of vibrant and independent JSC.
\end{abstract}

Keywords: Independence, Judiciary, Judges, Justice of Appeal, Chief Justice, Judicial Service Commission

\section{A: Background of Judicial Service Commission}

Judicial council is a civil law invention, it has been likened to similar bodies in operation in common law countries-for example, the U.S. Federal Judicial Conference or the judicial service boards and commissions found in Commonwealth nations. ${ }^{1}$ In 1946, France was the first State to have a body like a judicial commission that addressed the selection of judges and magistrates - called the Conseil Superior de la Magistrature. In 1958, Italy was the next country to have an organ similar to judicial council, named the Consiglio Superiore della Magistrature. ${ }^{2}$ The French-Italian model has been exported to Latin America and

* Diploma in Law (Institute of Judicial Administration Lushoto), LL.B (Mzumbe University), LL.M (University of Dar es Salaam), Postgraduate in Legal Practice, (Law School of Tanzania), Dr. juris. (Chemnitz University of Technology-Germany). The author is an Assistant Lecturer at the Institute of Judicial Administration Lushoto. He can be contacted by email: 1xndr_mrtn77@yahoo.com.

1 Hammergren, L., "Do Judicial Councils Further Judicial Reform? Lessons from Latin America," Working Paper: Rule of Law Series, Democracy and Rule of Law Project, No. 28, June 2002, p. 2.

2 Thuku, N., "A Comparative Analysis of Judicial Councils in the Reform of Judicial Appointments between Kenya and England," Annual Survey of Int'l \& Comp. Law, Vol. xix, (2013), p. 48. 
other developing countries. Indeed, the World Bank and other multilateral donor agencies have made judicial councils part of the standard package of institutions associated with judicial reform and rule of law programming. ${ }^{3}$

The first Latin America judicial council consciously modeled on European trends was established constitutionally in Venezuela in 1961 (although not actually formed until 1969). It was created to manage judicial appointments. ${ }^{4}$

In case of Kenya, Uganda and Tanzania, Judicial Service Commissions as institutions were not part and parcel of colonial judicial administration. The appointment of judicial officers was the prerogative of the governor and in some instances of His (or Her) Majesty. These commissions found route in the constitutions of these countries vide the independence constitutions. For example the appointment of puisne judges was made by the Governor-General acting in accordance with the advice of the Judicial Service Commission. ${ }^{5}$ It must not be forgotten that the independent constitutions were styled in the Westminster model. It was necessary for the leaving colonial masters to forge for the inclusion of democratic principles which they neither cherish nor paid attention and respect during the colonial times. Many principles, indeed, were transplanted to the independent states of Kenya, Uganda, Tanzania and most of African countries if not all. They were indeed meant to be protective of their personal and property rights against intrusion of the new government.

Sir Fred Phillips reiterates that scenario when he observes that the constitutions written for countries achieving independence in Africa were prepared by lawyers guided by the colonial office in the respective capital towns. He notes that these constitutions contained a clause stating that judges would be appointed following the advice of judicial commissions. ${ }^{6}$

It should be noted that upon attaining independence, the nationalist governments which acceded to power in all British colonies in Africa were to operate within a framework provided by the constitutions, agreed upon by both sides. This meant that the independence of any particular British colony, Tanganyika not being an exception, was always preceded by constitutional negotiations between nationalist leaders on the one side and the departing colonial master on the other. The British made it compulsory for the majority of its colonies at independence to include in their independence constitutions provisions limiting the powers of the government and introducing enforceable Bills of Rights which safeguarded human rights and freedoms. ${ }^{7}$ In those negotiations, Tanzania rejected the inclusion of Bill of

3 Garoupa, N., \& Ginsburg, T., "The Comparative Law and the Economics of Judicial Councils," Berkeley Journal of International Law, Vol. 27, No. 1, (2009), p. 5.

4 Ibid.

5 Articles 58 \& 59 of the Independent Constitution of Tanzania, 1961.

6 Ibid.

7 Ruhangisa, J. E., "Human Rights in Tanzania: The Role of the Judiciary," a Thesis Submitted to the University of London for the Degree of Doctor of Philosophy, Law Department, School of Oriental and African Studies, p. 46. 
Rights, ${ }^{8}$ but the appointment of judges upon recommendations made by JSC sailed through. Ordinary convention dictates that it was easy during independence to accept the appointment of judges upon the recommendations from the JSC as that was not considered a threat to independent Tanganyika as compared to accepting the enforceability of Bill of Rights.

The question now remains on whether the JSC of Tanzania with the current composition can effectively discharge the function of protecting the independence of judiciary and keeping the judicial organ accountable. In the same line it is important to review the composition, the functions and the independence of the JSC and examine if they can really fulfill such a noble function which intends to keep the judicial organs always independent and impartial.

\section{B: Meaning and Rationale of JSCs}

Judicial councils are bodies designed to take appointment and promotion of judges away from the partisan political process, while ensuring some level of accountability. Judicial councils fall somewhere in between the polar extremes of letting judges appoint their own successors and maintain internal responsibility for judicial discipline, and the alternative of complete political control of appointments, discipline, and promotion. ${ }^{9}$ This nomenclaturei.e. JSC - is not the same all over the world. In other jurisdictions the commissions have been given different names. So these commissions are also referred to as "judicial councils" or "merit commissions" 10 or "judicial appointments commissions." However, the mandate or functions are more less the same but their composition differs from one country to another.

Hammergen, ${ }^{11}$ Garoupa and Ginsburg ${ }^{12}$ find JSCs as important institutions which act as a shield to judges from involvement of the executive in selection of judges and at the same time ensuring accountability of judges.

The rationale for having judicial commissions is not difficult to establish. The judiciary being an organ which must operate independently from other organs of the state must govern its operations. It is therefore important for giving the doctrine of separation of powers its practical existence not to subject judicial officers and other employees to the whims of other organs of the state. This function is vested to the JSC. The JSCs are very important for ensuring self-regulation of the judiciary as a separate organ of the government.

8 Ibid.

9 Garoupa, \& Ginsburg, op. cit., p. 57.

10 Thuku, op. cit., p. 46.

11 Hammergren, loc.cit.

12 Thuku, op. cit., p. 48. 


\section{C: Constitutional and Legal Foundation of JSC of Tanzania}

The JSC of Tanzania is the creature of the constitution. The Constitution of the United Republic of Tanzania (CURT) under Article 112 (1) establishes the JSC. It provides to the effect that there shall be an Appointments Advisory Commission for Judges and Magistrates in Mainland Tanzania which in this Constitution shall be known as the "Judicial Service Commission." The Proposed Constitution 2014 establishes the same under section 199(1). It has to be pointed quickly here that the JSC of Tanzania is not a union matter. Zanzibar has in place its own JSC.

The JSC, therefore, in Tanzania occupies a special place and is constitutionally safeguarded. Being in the constitution signifies the importance of the Commission and therefore it becomes more difficult to de-establish it than if it were only established by ordinary statute. However, the constitution gives power to the Parliament to enact laws providing for the structures, procedures, functions and to regulate the conduct of affairs of the Commission. ${ }^{13}$ Tanzania enacted the Judiciary Administration Act of 2011 which repealed and replaced the Judicial Service Act of 2005. Section 13 (1) \& (2) provides that there shall continue to be the Judicial Service Commission established by the Constitution. Members of the Commission appointed by the President shall hold office for three years but shall be eligible for reappointment for one further term.

\section{D: Legal Mandate of the JSC}

The functions of the JSC of Tanzania are enumerated under Article 113 (1) (a)-(f) of the CURT being, to advise the President regarding appointments of the Judges of the High Court; to advise the President on matters relating to discipline of judges; to advise the President in relation to salaries and remuneration for judges; to advise the President in respect of appointment and discipline for Registrar of the Court of Appeal and the Registrar of the High Court. A cursory look at the above provision signifies that JSC is neither exclusively involved in the appointment of judges nor empowered to discipline judges of the High Court and Court of Appeal. In these two functions the involvement of the executive is obvious and makes the independence of the judiciary to be suspicious.

The function to promote and facilitate independence and accountability of the judiciary is cherished by legal stakeholders and appears to be the paramount function but that function is not constitutionally and legally stipulated. It must be noted that promotion of independence of the judiciary is an essential function which by its inclusion in the constitution empowers the JSC to come forefront whenever the independence of the judiciary or of itself is interfered or there is likelihood of interference. 


\section{E: Composition and Appointment of JSC}

The system of appointment of members of any commission has a direct bearing on the integrity, impartiality and independence of the persons appointed to constitute the commission. If the appointments are politicized, the public will lose confidence in the members and the commission at large. The process and the standards employed during the appointment of the members are critical to the independence and integrity of those appointed.

The composition and the mode of appointment of members of the JSC speak volumes on the independence and impartiality of the persons appointed. It is, therefore, pertinent here to look at the composition and appointment to see if they can afford a robust and vibrant JSC.

The JSC of Tanzania is composed by six persons as provided for under Article 112 (2) of CURT namely: the Chief Justice who shall be the Chairman; the Attorney-General; a Justice of the Court of Appeal of Tanzania who shall be appointed in that behalf by the President after consultation with the Chief Justice; the Principal Judge; and two members who shall be appointed by the President. The constitution provides in clear terms that a person shall not qualify to be an appointed member of the Commission under the provisions of paragraph (e) of Sub-Article (2) of this Article, if he is a member of parliament or the holder of any other office prescribed in that behalf by a law enacted by the Parliament. ${ }^{14}$

Directly or indirectly all members of the JSC are the appointees of the President and those who are not appointed by the President but are members by virtue of their posts have been appointed to those posts by the President in a manner that leaves a lot to be desired. It must be noted be forgotten that the appointment of members such as the Chief Justice, the Attorney General and the Principal Judge is the exclusive domain of the President. The reasons, let alone the process for their appointment leave a lot to desired and cast doubts on their independence and impartiality. This does not mean to say that whoever is appointed by the President becomes automatically dependent and partial in relation to the appointing authority. However, likelihood of the same should not be ignored.

\section{F: Independence of the Commission}

Independence of any institution created either by the constitution or by any ordinary law becomes a prerequisite for the proper and effective functioning of such an institution. If institutions are not de jure and de facto independent then such institutions are redundant and likely that they cannot efficiently discharge their constitutional essential functions to the optimal required standards.

Independence of any entity can be looked at from two perspectives. The first one is whether the law establishing the entity provides in clear terms for independence of such entity and if that is not provided one has to resort to the structure of the entity as a whole. The

14 Art. 112 (3) of the CURT. 
manner the provisions are crafted is of great importance. It is possible as it is the case for many institutions in Africa that independence is statutorily given but reading the provisions establishing the institutions in context, it is not unlikely to discover that the institutions created cannot exercise their independence. On the other hand it is possible, but in few cases, to find no express provision on independence of a particular institution but the way the provisions are crafted act as a shield against dependence to any authority or person.

In case of Tanzania, all members of the JSC are the appointees of the President. It goes without saying that the President has implicitly much influence on the Commission. This is a dangerous state of affair. However, being the appointees of the President alone does not mean the Commission cannot be independent. What is intended to with regard to independence is to give the JSC exclusive power on the appointment and discipline of the judges and registrars to remove the hands of the politicians in the administration of the Judiciary. The removal process of the judges whether of the High Court or Court of Appeal should start from the JSC. The President therefore should initiate the constitutional process after the recommendations from the JSC.

\section{G: The Role of the JSC in Appointment of Judges}

The JSC plays an important role in the appointment of judges in Tanzania. However, it must be gathered from the outset that this function is limited in a number of ways.

First, the role of the JSC is only to recommend and that recommendation is only for the appointment of judges of the High Court. The second limitation is that the JSC is not involved in the appointment of the Chief Justice and Justices of the Court of Appeal. This function is the exclusive domain of the President. In case of the appointment of the CJ the JSC is not involved.

In case of the appointment of Justices of Appeal, the President appoints them in consultation with the CJ. In this process again, the JSC is not involved. The two processes cast doubt to the general public on the independence of those appointed. It is not clear which criteria are used by the appointing authority to nominate them. In absence of transparency those appointed may likely become supplicants of authority which appointed them. In other jurisdiction like Kenya, the President involvement is not completely removed but the provisions of the constitution are crafted in such a way that the appointment by the President is merely ceremonial. The President becomes duty bound to nominate the name of the CJ forwarded to him.

But what takes place within the JSC during the process of appointing judges is not apparent to most of the people in the legal fraternity. Most of the lawyers and judicial officers cannot tell. Whatever the procedure JSC had been adopting in the final analysis it had to recommend the names to the President. No one could know which names have been forwarded but no one can also tell whether all the judges so appointed have had been appointed from the list submitted to the President by the JSC. 
What recourse does a person who has been recommended to the President is not appointed and instead a person who was not even recommended is appointed? At first place how would he know that he was recommended? It is obvious that if the whole process was neither competitive nor transparent it becomes difficult to know the list which was recommended to the President. One element for independence of the JSC is to have power to make binding recommendation to the President who is the appointing authority. The JSC has to scrutinize the names of suitable candidates for appointment once satisfied and forward the names to the President for appointment. The President should constitutionally be bound by the list given to him.

The JSC of Tanzania, being an advisory body; the President is not bound by its recommendations. It depends on the good will of the President to respect the recommendations from the constitutional body and thereupon to exercise his discretion judiciously. The legal effect of recommendation has been a subject of discussion but Article 37 of the CURT decelerates the debate to rest.

The provision states that, "in discharge of his functions the president is not obliged to follow the advice of any body or person unless it is so provided by the constitution or any other law." In case of appointment of judges no such binding character is imposed to the President. The President may therefore appoint judges from the list or not. And in doing so he does not violate any constitutional provision. The appointment of judges has been somewhat controversial to the extent of doubting some of the names recommended by the JSC.

Recently, the JSC of Tanzania adopted slightly a new process in the whole exercise of recruiting judges. On $18^{\text {th }}$ July, 2016, for the first time in the history of Tanzania, the JSC made an advert in the government newspaper circulating in the country on the vacant positions of judges and called Tanzanians interested and with qualifications set out in the constitution to apply. The CJ of Tanzania was quoted in Mwananchi newspaper of $19^{\text {th }}$ July, 2016 saying that; "We have decided to adopt this procedure in order to increase transparency, broaden the scope and increase competition in order to get qualified judges. This is the procedure within the commission and we have been discussing about it so often within the commission, but we had not implemented it. This time we have decided to try to expand the scope by advertising." While this was a commendable stride which received warmth welcome, it is skeptical if it will increase such transparency if the procedure ends to advertising. The sole thing that such a procedure will serve is to enable the JSC to sort the names from the pool of applicants. Though, I am not inclined to believe that the commission will be bound to make selection from the applicants only for the reasons which I am going to provide shortly hereafter.

First, the call for application was discriminative as it had excluded magistrates from applying. It was stated in clear terms in the advert that magistrates should not apply as they have their own special internal procedure. It is unfortunate that most of the magistrates claim to have no idea of the procedure. One can ask several questions like why different procedures for persons applying for similar post? Is it fair to involve one category of per- 
sons to transparent process as it seems to be and subject others to an appointment process which is shrouded with secrecy as before? Such a state of affair does not give hope that the process will be transparent as contended by the CJ.

And what is more interesting in the advertisement "magistracy" has been mentioned as one of the qualifications but the same magistrates are excluded from applying. Then such a qualification of being a Magistrate was redundant on the face of it.

Second, the whole procedure was not backed by the law. This simply means the procedure remains fragile. It is for interest of justice and fair play that important procedures are backed by the law so that people may assess fairly its application without fear of changes according to the whims of one person or group of persons.

Since the first batch of judges appointed following an advertisement, the appointments which followed that have taken the old style. It follows, therefore that the procedure which was intended to increase transparency has died swiftly. It is then unfortunate that the Commission did not initiate legislative process to legalize the process. At least the CJ should have promised for steps to be taken to back the process by the law. The legal process is insisted because appointment process of judges has a direct bearing to the nature of the judge who is going to be appointed. It has been agreed that a process tainted with secrecy is susceptible in some instances to bring on board incompetent, dependent, impartial, partisan, corrupt and even sympathetic judges.

\section{H: The JSCs and Independence of the Judiciary: The Nexus}

The nexus between independence of the judiciary and the JSC is not difficult to unveil. This is so because the hallmark of proper administration of justice depends on the effectiveness and efficiency of the JSC. It is however known that other organs of the government should support institutionalizing independence of the judiciary. For example Article 165 (4) of the Constitution of the Republic of South Africa provides that "organs of the State, through legislative and other measures, must assist and protect the courts to ensure the independence, impartiality, dignity, accessibility and effectiveness of the courts." So to create independence of the judiciary cannot be a one man show. It should involve all stakeholders in the legal fraternity and even those outside it because every living creature needs justice.

It is also incomprehensible to visualize proper administration of justice if the judiciary is neither independent nor impartial. It is upon the JSC to protect the judiciary. The good thing of the JSC of Tanzania is led by CJ as Chairperson of the commissions. It is expected that the CJ will always strive to rebuke all those who interfere or attempt to interfere the independence of judiciary.

It is worth at this juncture to let the Chairman of the JSC and the CJ of Kenya speak of the role of the JSC, he utters that: "The JSC, which is composed of judicial officers as well as representatives of the legal fraternity, the government and the general public, is constitutionally mandated to protect the independence of the judiciary, and is duty-bound to speak 
up when that independence is threatened. ${ }^{15}$ As said earlier, the constitution has no provision seizing independence to the JSC but it can be deducted from the provision mentioned above that in order to discharge that duty the JSC has to be independent. That is the function which has to be exercised by any JSC regardless whether there is a provision saying so or not.

\section{I: Conclusion}

In order to establish an independent and effective judiciary capable of ensuring the prevalence of rule of law and protection of human rights, it is momentous to make surgery of the JSC. The JSC should be given absolute powers to deal with the appointment and discipline of all judicial officers.

In order to be able to get independent and impartial members of the commissions, it needs the broad reconstruction of the manner some members such as the CJ, CJs, Principal Judges (PJs) and judges are generally appointed. It is important and imperative to avoid opacity in their appointment process. The more independent JSCs are, the more credible they become and command respect from the public when discharging their functions.

15 Mutunga, W., "Judicial Service Commission (JSC) Statement on the Independence of the Judiciary," delivered on March 2, 2014, p. 2. 